\title{
Examination of Human Psychological Needs according to Islamic Teachings
}

\author{
Hassan Rezaee Haftador ${ }^{1}$ \& Eshaq Hoseyni Koohsari ${ }^{1}$ \\ ${ }^{1}$ Hadith and Qur'anic Sciences Department, University of Tehran, Iran \\ Correspondence: Hassan Rezaee Haftador, Hadith and Qur'anic Sciences Department, University of Tehran, Iran. \\ E-mail: hrezaii@ut.ac.ir
}

Received: December 22, 2014 Accepted: February 3, 2015 Online Published: June 5, 2015

doi:10.5539/ass.v11n18p93

URL: http://dx.doi.org/10.5539/ass.v11n18p93

\begin{abstract}
Every day, mental illnesses bring about significant economic, social, and personal loss. It is for this reason that investigation of human psychological needs is essential. Failure to meet these needs may result in mental disorder. Keeping the psyche healthy and securing peace of mind are some of the main concerns of monotheistic religions, especially Islam. The psychological needs of human beings addressed in the teachings of Islam are examined in the present study. According to Islamic teachings, the most important mental needs of humans include safety, love, self-esteem, knowledge, beauty, self-actualisation, and prayer.

Quranic teachings maintain that fulfilment of psychological needs not only prevents mental disorders, but also acts as a prelude to worshiping God since humans attain sustainable peace through worship.
\end{abstract}

Keywords: psychological needs, human beings, Islamic teachings, Quranic teachings

\section{Introduction}

Anxiety and depression are disorders from which many people suffer. They are, in fact, the most prevalent mental disorders. Proliferation of psychological conditions throughout the world lead the World Health Organisation (WHO) to start a new programme of mental health services. In 1961, a great social psychiatry movement began in the USA, which was called by some 'the third great revolution'.

Specialists have estimated that the onset of $80 \%$ of all modern diseases coincides with psychological pressure. Considering that mental illnesses bring about significant economic, social, and personal loss every day, it is essential that the psychological needs of human beings be investigated. Failure to meet these needs can result in mental disorder. Thus, utilising a descriptive and analytic approach, the present research seeks to answer the question: According to Islamic teachings, what are the psychological needs of human beings, and what are the effects of fulfilment of such needs?

\section{Human Psychological Needs}

Over the course of history, Islam has attracted millions of people from various ethnicities and geographical locations. It has changed their lifestyles and has given their lives a special purpose. It has also provided them with rules and guidelines for personal and social life. Doubtless, such a religion utilises a special psychological system. Some of the main concerns of monotheistic religions, especially Islam, include solving mental problems and securing peace of mind (Ahmadī, 1993, p. 806). The following are the most important psychological needs of humans according to Islamic teachings.

\subsection{Safety}

If the physiological needs of a person are satisfied relatively well, a new set of needs emerge that can be generally considered as safety-related needs (Shāmlū, 1993, pp. 136-146; Muḥy al-Dīn Bunāb, 1995, pp. 38-39; Maslow, 1995, pp. 82-83).

There is a difference between the need for safety according to the Islamic view and the materialistic perspective. In a materialistic view, this need is a purpose. However, in Islam, it is a precondition for attaining the goal of becoming God's representative (caliph) upon the earth. An outcome of the difference between these views is as follows. Any kind of threat to the materialistic human leads to loss of inner balance since the secular person is limited to worldly time and space; they have nothing but a finite lifetime and a restricted area in which to live. 
However, this is not so for the believer. The misfortunes throughout life are replaced with spiritual values, otherworldly blessings, and divine destiny. For believers, worldly life is a bridge to eternal life in the next world. On the other hand, persons whose sole purpose in life is attaining everything possible in this world knows no bounds in satisfying their desires (Majlisī, 1984, vol. 73, p. 7).

When there is a threat to the law, order, and government of a society, the need for safety is urgent. In such a situation, it is to be expected that in most people nihilism and fear of chaos will result in regression from higher needs and prioritisation of the overwhelming need for safety (Ṭabāțabāà̄, 2010, vol. 11, pp. 79-109).

In the teachings of Islam, order is considered one of the principles of psychological health (Tabrisī, 1986, pp. 543-544, p. 363; Maybudī 1993, pp. 499-500; Razī, 2000, pp. 469-470; Ṭūsī, 1982, p. 534; Ibn Kathīr Damishqī, 1998, pp. 59-60).

With respect to law and order, Islam advises the following.

a. All needs relating to order must be taken into consideration

b. People must dedicate themselves to positive activities and avoid disorganisation (Ākhūnd Khurāsānī, 2008, vol. 2, p. 249)

c. People must place importance on their connection with God

d. People must manage the affairs in their lives

e. People must satisfy their desires and achieve permissible pleasures (Ibn Shu'bah Ḥarrānī, 1984, p. 11)

f. People must practice moderation and refrain from excess (Quran 2:143; Suyūțī, 1984, vol. 1, p. 144; Zamakhsharī, 2006, vol. 1, pp. 198-199; Rāzī, 1988, vol. 2, pp. 196-197; Ḥusaynī Shāh 'Abd al-'Azīmī, 1984, vol. 1, pp. 274-275).

\subsection{Love}

After satisfying physiological and safety-related needs, the need for love and affection manifests itself. In this situation, persons thirst for relationships with other people, and forget that there was a time when they were hungry and attached no importance to love - a time when they ridiculed love. Now, however, they strongly feel the pain of loneliness, isolation, abandonment, and absence of friends (Maslow, 1995, pp. 79-81). The need for love includes both the need to love and to be loved (Muhy al-Dīn Bunāb, 1995, pp. 49-53).

Love is the basis of religion according to Islamic teachings (Kulaynī, 1984, p. 79; Huwayzī, 2010, pp. 83-84).

Love is not only one sided. It draws a person to fulfil the desires of the beloved. This makes the beloved interested as well. Basically, the bond of love draws a person toward the beloved and the desires of the beloved, and the more this motivation grows, the stronger the attraction becomes (Qumī, 1936, p. 201).

The Quran declares to those claiming to love God, 'If you love Allah, then follow me; Allah will love you...' (Quran 3:31).

The story of the brothers of Prophet Joseph is the best example of abandonment and psychological pressure in the Quran. When they felt that their father loved Joseph and Benjamin more (Quran 12:8), they decided to murder Joseph. Thus, they became the agents of destruction of Jacob's family (Qumī Mashhadī, 1989, p. 276; Tha'âlibīi, 1997, p. 312; Țabarī, 1991, pp. 92-93). It may be said that like a strong adhesive, love joins the components of a human society. Without love, people separate from each other and the society crumbles (Makārīm Shīrāzī, 1996, p. 392).

In the Quran, God gives believers the following tidings.

'Indeed those who have faith and do righteous deeds - the All-beneficent will endear them [to His creation]' (Quran 19:96).

Through the principle of love and fulfilment of needs, the teachings of Islam seek to reform the people. The principles of love and fulfilment of people's needs is completely contrary to enmity and rancour. In Islam, the need for love is satisfied through expression of love and drawing close to other people (Majlisī, 1984, vol. 74, p. 181, 393; vol. 75, p. 265; vol. 77, p. 149).

The commandments of saying 'saläm', making an effort to be the first to say it, and displaying affection are indicative of the efforts of Islam to attract people's hearts toward one another and spread affection. The Quran considers one of the distinguishing traits of prophets to be their love and compassion for the people (Quran 7:79; 9:128; 26:3; Ṭayyib, 1999, vol. 5, p. 373; Sūr Ābādī, 2002, vol. 2, p. 771; Ālūsī, 1994, vol. 4, p. 404). 
The exchange of affection is a major issue in the society. Every person needs the affection of others. It is for this reason that visiting relatives is an important issue in Islam. Of course, believers make friends and enemies for God. They hasten to visit other believers and exchange affection due to their love for God.

\subsection{Self-esteem}

People living in a society desire a feeling of respect for themselves and also desire to show respect to others. Fulfilment of self-esteem brings about self-confidence, and neglect of self-esteem leads to a feeling of inferiority, weakness, and helplessness (Maslow, 1995, pp. 82-83). Accordingly, many negative reactions stem from lack of self-esteem. Healthy, genuine self-esteem is based on due respect from others as opposed to superficial reputations and undue praise. Secular people seek love and gratitude. They are intent on attaining great fame and social status. However, Muslims endeavour to attain a personality commensurate with the divine mission entrusted to them since in the Islamic perspective, greatness belongs to God, the Prophet of Allah, and other believers.

The value given to self-esteem in Islamic teachings prevents people from performing ignoble and improper deeds (Hurr 'Āmilī, 1973, vol. 3, pp. 343, 351, 376). In the Quran, attention to self-esteem is a fundamental concept since humans are considered the best of all creatures (Quran 17:70; 23:14; 25:72; Tha'labī Nīshābūrī, 2001, vol. 6, pp. 114-115; Sayyid ibn Quṭb, 1991, vol. 4, pp. 2240-2241; Baḥrānī, 1995, vol. 3, p. 550; Ḥusaynī Hamidānī, 1984, vol. 10, p. 111; Thaqafì Tihrānī, 1978, vol. 3, pp. 378-379).

On human dignity in Islam, it is sufficient to say that humans do not have the right to worship any being save God. Only He can be worshiped, and no other has this right. A person who desires greatness must know that all greatness belongs to God (Quran 35:10; Qurashī, 1998, vol. 9, p. 20; Mughniyyah, 2003, vol. 6, p. 281; Kāshānī, 1957, vol. 7, p. 393; Șādiqī Tihrānī, 1984, vol. 24, p. 309; Andalusī, 1999, vol. 9, p. 17).

\subsection{Knowledge}

The human quest for knowledge is aimed at satisfying curiosity. Humans seek the truth in the face of the greatest of dangers, even the risk of death. They are fascinated by mysterious and unknown phenomena. On the other hand, they exhibit a weary or jaded response to known phenomena. Boredom, depression, and self-hatred manifest themselves in intelligent persons who are wasting their lives on banal professions. Humans become weary of old things, and things that satisfy the human need for exploration quickly lose the gratification they previously provided (Maslow, 1995, pp. 85-89).

Islam extends the rewards of martyrdom, the greatest spiritual status, to seekers of knowledge (Tabrisī, 1986, vol. 9, p. 235).

The first Quranic verses that were revealed to the Prophet of Islam concerned knowledge (Quran 96:4-5; Sabziwārī Najafī, 1998, vol. 1, p. 603; Ṭāliqānī, 1986, vol. 4, p. 181; Fayḍ Kāshānī, 1994, vol. 5, p. 349). In the Quran, after speaking of the blessing of creation, God speaks of knowledge (Quran 55:3-4; Shubbar, 1991, vol. 1, p. 496; Sharīf Lāhījī, 1994, vol. 4, p. 327; Faḍl Allāh, 1998, vol. 21, pp. 303-304). The Quran asserts that the angels bowed to Adam when he gained divine knowledge (Quran 2:31; Jurjān̄ī, 1998, vol. 1, p. 64; Husaynī Shīrāzì, 2003, vol. 1, p. 120). The status of knowledge is so high that God commands Muhammad, the Prophet of Islam, to say, 'My Lord! Increase me in knowledge' (Quran 20:114).

Even though Prophet Moses held the rank of prophethood, he followed Prophet Khidr to gain knowledge (ibid 18:66).

Even though Prophet Abraham had reached a lofty spiritual status, he asked God to show him how the dead come back to life so he could reach the state of certainty (Quran 2:260; Bayḍāwī, 1998, vol. 1, p. 157; Ibn Shahr Āshūb Māzandarānī, 1990, vol. 1, pp. 221-222). This event demonstrates that even if a person is given divine knowledge and the rank of a prophet, the person seeks certainty and peace of heart through yet better understanding; in other words, there are various levels of certainty, and Prophet Abraham sought to reach a higher level.

When prophets, who have been satiated from the springhead of divine knowledge, seek inner peace in higher understanding, it is clear what normal humans must do as, in actual fact, they have very little knowledge (Quran 17:85).

\subsection{Beauty}

Some people have a real aesthetic need. They become ill by observing ugliness and recover their health when they stay in a beautiful environment. Such people are brimming with a sort of enthusiasm that only beauty can 
satisfy. The human interest in beauty has existed from the era of cave-dwelling until today (Maslow, 1995, p. 89).

Love for beauty is one of the four aspects of the human soul that creates literary and poetic beauty as well as arts and crafts. Islamic teachings also lay importance on this aspect of the human soul (Quran 7:32; (Hurr ' $\bar{A}$ milī', 1973, vol. 3, pp. 341). According to the teachings of the Quran, God has commanded that believers wear their adornments when entering a mosque (Quran 7:31; Marāghī, n.d., vol. 8, p. 133; Zuhaylī, 1997, vol. 8, p. 183).

Having an aesthetic perspective toward the universe is a type of worship. When observing beauty, believers feel not only pleasure, but also a kind of obeisance toward the Lord. Obviously, there are Islamic rules about beauty and use of adornments just as there are rules about use of all other blessings.

The important rules for use of adornments in Islam include the following.

a. Use of adornments must not lead to stigmatisation or distinction in the society (Hurr ' $\bar{A}$ milì, 1973 , vol. 1, p. 354).

b. The use of God's blessings and adornments must adhere to the prohibition of wasting. Therefore, excess in use of adornments with the aim of arrogance and vaunting is forbidden (Quran 26:128-129).

\subsection{Self-actualisation}

Self-actualisation refers to realisation of the potentials that lie within a person. Self-actualisation may manifest itself as the tendency to become a champion, inventor, or something similar. Visible manifestation of self-actualisation usually requires fulfilment of lower needs including physiological needs, safety, love, and self-esteem (Maslow, 1995, pp. 82-84).

Self-actualisation is exhibited in a person with a strong need for advancement - a person who wants to improve their performance. The following are specifications of advocates of progress and development.

a. They do not seek easy work.

b. They seek out tasks that are not comparable with the work of others.

c. They are diligent.

d. They have high aspirations.

The Islamic view on self-actualisation may be summarised as follows. Humans are like gold and silver mines, and the prophets have been sent to extract these ores.

As indicated in the Quran, no creature's arcs of descent and ascent (qaws șu ûd wa nuz $\bar{u} l$ ) are as lengthy as those of human beings. In the arc of ascent, angels prostrate themselves before human beings (Quran 38:71). Humans become the vicegerents of God upon the earth (ibid 2:30). They are creatures that have been created in the best possible way (ibid 23:14), and on the condition that they perform good deeds, they will become the best of creatures (ibid 98:7). In the arc of ascent, humans can reach a state where they perceive nothing but God (ibid 53:8-9).

According to the teachings of the Quran, humans on the arc of descent are described as lowlier than animals (ibid 7:179). Their hearts can become harder than stones (ibid 2:74). Ultimately, they can plummet to the lowermost depths of hell (asfal al-sāfilīn) (ibid 4:145; Makārīm Shīrāzī, 1996, vol. 27, p. 144).

In this path of climb and descent, humans are responsible and have free will; they reap what they sow (53:39; Țabātabā̄̄ī, 2010, vol. 13, pp. 189-194; Jawādī Āmulī, 1993, pp. 30-35).

The teachings of Islam endeavour to make humans view themselves positively, enjoy a feeling of independence, and avoid negative thoughts, inferiority, weakness, and uncertainty.

Naturally, self-actualisation must go hand in hand with acceptance of reality and correct self-assessment. Such assessments must accompany trust in the power of God along with personal endeavours in order to lead a person to their final destination (Bustān̄i, 1993, pp. 248-274).

\subsection{Worship}

In most religious books, three main factors are discussed concerning worship including religious vows and sacrifice, confession and repentance, and prayer to God (James, 1964, p. 152).

The need for worship and prayer is one of the oldest and most solid manifestations of the human soul as well as one of the fundamental aspects of human existence. Investigation of traces of human life reveals that wherever humans lived, worship and prayer existed as well though the god being worshiped varied. Prophets have not 
taught humans worship itself, but rather the manner in which to worship. In this way, they sought to prevent polytheism. Many scholars believe that humans were initially monotheists but later deviated from the path. The tendency to worship, which is sometimes called the religious sense, exists in every human being (Muțahharī, 1982, p. 105).

Research on depressed people and criminals has demonstrated that those who accept religious beliefs or are somehow connected with a place of worship have loftier characters. In comparison with those without faith and who do not worship, they have a sort of nobility (Țayyārah, 2003, p. 9).

According to researchers in the area of human mental health, persons who go to church once a week have less psychological problems (Riḍwān Țalab, 1996, p. 24).

If a person spends an hour every day for worship and speaking with the Lord, their souls will be greatly purified (Muțahharī, 1982, p. 292).

In times of difficulty and pressure, humans invariably seek refuge in supernatural powers. The Quran announces that when humans lose hope in material causes, they remember God and ask Him for help (ibid 10:12).

According to the Quran, God's purpose for creating humans and jinn was for them to worship their Lord (ibid 51:56; Qumī, 1988, vol. 2, p. 331). This is because worship is the ultimate state of human perfection, proximity to God, and submission to Him.

\section{Conclusion}

Since solving mental problems and securing peace of mind are two of the main concerns of Islam, its teachings take the psychological needs of human beings into consideration. The most important of these needs include safety, love, self-esteem, knowledge, beauty, self-actualisation, and worship. In the view of Islam, safety is not a goal in and of itself, but rather a prelude to achieving proximity to the Lord.

According to Islam, love and affection are not one-sided since love induces a person to fulfil the desires of the beloved. This display of affection makes the beloved interested in return.

The exchange of affection is a major issue in the society. Every person is in need of the affection of others. It is for this reason that visiting relatives is an important issue in Islam.

Islamic teachings prevent people from performing ignoble and improper deeds that are contrary to self-esteem. In the Quran, self-esteem is a fundamental concept since human beings are the greatest of God's creations. A person who desires greatness must know that all greatness belongs to God.

The Quran teaches that acquisition of knowledge leads to mental peace.

According to the Islamic view, having an aesthetic perspective toward the universe is a type of worship. When observing beauty, believers feel not only pleasure, but also a kind of obeisance toward the Lord.

The teachings of Islam endeavour to make humans view themselves positively and, in this way, Islam lays the foundations for self-actualisation.

A person can cleanse their souls to a great degree by spending an hour every day for worship and speaking with their Lord.

\section{References}

Aḥmadī, A. (1993). Mushāvirah va Ravān Darmānī. Isfahan: University of Isfahan.

Ālūsī, M. (1994). Rūh al-Ma āñ̄ fì Tafsìr al-Qur'ān al-'Aẓ̂̀m wa al-Sab 'al-Mathānī. ed. 'Alī 'Abd al-Bārī 'Ațiyyah, Beirut: Dār al-Kutub al-'Ilmiyyah.

Andalusī, A. H.. M. ibn Y. (1999). Al-Bạ̣r al-Muḥịtfí al-Tafsīr. Beirut: Dār al-Fikr.

Bahrān̄̄i, H. (1995). Al-Burhān fì Tafsīr al-Qur’ān. Tehran: Bunyād Bi'that.

Bayḍāwīi, 'A. A. (1998). Anwār al-Tanzīl wa Asrār al-Ta wìl. Beirut: Dār Ihyā’ al-Turāth al-'Arabī.

Bustānī, M. (1993). Islām va Ravān Shināsī. tr. Maḥmūd Huwayshim, Mashhad: Āstān Quds Raḍavī.

Faḍl Allāh, M. Ḥ. 1998). Tafsìr min Waḥy al-Qur ān. Beirut: Dār al-Milāk li-al-Ṭibācah wa al-Nashr.

Fayḍ Kāshānī, M. (1994). Tafsìr al-Ṣâfì. Tehran: Intishārāt al-Șadr.

Ḥurr 'Āmilī, M. ibn Ḥ. (1973). Wasā̄il al-Shīáah, ed. 'Abd al-Rahīm Rabbānī Shīrāzī, Tehran: Al-Maktabah al-Islāmiyyah.

Ḥusaynī Hamidānī, M. Ḥ. (1984). Anwār Dirakhshān. ed. Muḥammad Bāqir Bihbūdī, Tehran: Kitābfurūshī 
Luții.

Ḥusayn̄̄ Shāh `Abd al-'Aẓīmī, Ḥ. ibn A. (1984). Tafsìr Ithnā 'Asharī. Tehran: Intishārāt Mīqāt.

Ḥusaynī Shīrāzī, M. (2003). Taqrīb al-Qur'ān ilā al-Adhhān. Beirut: Dār al-'Ulūm.

Huwayzī, ‘A. ‘A. (2010). Nūr al-Thaqalayn. Qum: Daftar Nashr Navīd Islām.

Ibid. (1991). Islām va Muqta diyāt Zamān. Tehran: Naṣir Khusraw.

Ibn Kathīr Damishqī, I. (1998). Tafsìr al-Qur’ān al- Aż̄im. Beirut: Dār al-Kutub al-'Tlmiyyah.

Ibn Shahr Āshūb Māzandarān̄̄, M. ibn 'A. (1990). Mutashābih al-Qur'ān wa Mukhtalifah. Qum: Intishārāt Bīdār.

Ibn Shu'abah Ḥarrānī, Ḥ. ibn 'A. (1984). Tuḥaf al-Uqūl 'an Āl al-Rasūl. ed. 'Alī Akbar Ghaffārī, Qum: Mu’assisah al-Nashr al-Islāmī.

James, W. (1964). Dīn va Ravān. tr. Mahdī Qā̄inī, Qum: Dār al-Fikr.

Jawād̄̄ Āmulī, 'A. A. (1993). Insān dar Islām. Tehran: Markaz Nashr Farhangī Rajā’’

Jurjān̄̄, Ḥ. ibn Ḥ. (1998). Jalā’ al-Adhhān wa Jalā’al-A ḩzān. Tehran: Intishārāt Dānishgah Tihrān.

Kāshānī, F. A. (1957). Tafsīr Manhaj al-Ṣādiqūn fì Ilzām al-Mukhālifìn, Tehran: Kitāb-furūshī Muhammad Hasan 'Ilmī.

Khurāsān̄i, Ā., \& Kāẓim, M. (2008). Kifāyah al-Ușūl. Qum: Dār al-Ḥikmah.

Kulayn̄̄, M. ibn Y. (1984). Al-Kāfì.ed. 'Alī Akbar al-Ghaffārī, Tehran: Dār al-Kutub al-Islāmiyyah.

Majlisī, M. B. (1984). Bị̣ār al-Anwār al-Jāmi áh li-Durar Akhbār al-A ïmmah al-Ațhār. Beirut: Mu’assisah al-Wafằ.

Makārim Shīrāzī, N. (1996). Tafsìr Nimūnah. Tehran: Dār al-Kutub al-Islāmiyyah.

Marāghī, A. ibn M. (n. d. ) Tafsīr al-Marāghī. Beirut: Dār Ihyā̄ al-Turāth al-'Arab̄̄.

Maslow, A. (1995). Ufuqhāa-yi Vālātar Fitrrat Insān. tr. Aḥmad Rị̣wān̄̄, Mashhad: Āstān Quds Raḍavī.

Maybudī, R. al-D. (1993). Kashf al-Asrār wa Uddah al-Abrārr. ed. 'Al̄̄ Asghar Hikmat, Tehran: Intishārāt Amīr Kabīr.

Mughniyyah, M. J. (2003). Tafsīr al-Kāshif. Tehran: Dār al-Kutub al-Islāmiyyah.

Muḥy al-Dīn Bunāb, M. (1995). Rawān Shināsī Angīzish va Hayajān. Tehran: Nashr Dānā.

Muțahharī, M. (1982). Ihyyā-yi Fikr Dīñ̄. Tehran: Kānūn Khadamāt Farhangī Alast.

Qumī Mashhadī, M. ibn M. R. (1989). Kanz al-Daqā ìq wa Baḥr al-Gharā ỉb. ed. Ḥusayn Dargāhī, Tehran: Vizarat Farhang wa Irshād Islāmī.

Qumī, 'A. (1936). Safinah al-Biḥ̄arr. Najaf: Mațba'ah al-'Ilmiyyah.

Qumī, 'A. ibn I. (1988). Tafsīr al-Qumī. Qum: Dār al-Kitāb.

Qurashī, 'A. A. (1998). Tafsīr Aḥsan al-Hadīth. Tehran: Bunyād Bi' that.

Rāzī, A. al-F. Ḥ. ibn 'A. (1988). Raw al al-Jinān wa Rūḥ al-Jinān fì Tafsīr al-Qur'ān, ed. Muhammad Ja'far Yāḥaqqīi, Mashhad: Bunyād Pizhūhishhā Islāmī Āstān Quds Raḍavī.

Rāzī, F. al-D. (2000). Mafātịh al-Ghayb. Beirut: Dār Ihyā’ al-Turāth al-'Arabī.

Rị̣̂ān Ṭalab, M. R. (1996). Parastish Āgāhānah. Qum: Intishārāt Mihr.

Sabziwārī Najafī, M. ibn Ḥ. A. (1998). Irshād al-Adhhān ilā Tafsīr al-Qur'ān. Beirut: Dār al-Tāāruf li-al-Mațbū'āt.

Șādiqī Tihrānī, M. (1984). Al-Furqān fì Tafsīr al-Qur āan bi-al-Qur'ān. Qum: Intishārāt Farhang Islāmī.

Sayyid ibn Quṭb, I. (1991). F̄̄ Zilāl al-Qur ān. Beirut: Dār al-Shurūq.

Shāmlū, S. (1993). Bihdāsht Ravānī. Tehran: Intishārāt Rushd.

Sharīf Lāhījīi, M. ibn ‘A. (1994). Tafsīr Sharīf Lāhījī. Tehran: Daftar Nashr Rād.

Shubbar, 'A. A. (1991). Tafsīr al-Qur 'ān al-Karìm. Beirut: Dār al-Balāghah li-al-Ṭibā'ah wa al-Nashr.

Sūr Ābādī, A. B. 'A. ibn M. (2002). Tafìr Sūr Ābādī. ed. 'Alī Akbar Sāīdī Sīrjānī, Tehran: Farhang Nashr Naw.

Suyūțī, J. al-D. (1984). Al-Durr al-Manthūr fì al-Tafsìr al-Ma thūr. Qum: Kitābkhānah Āyat Allāh Mar'ashī 
Najafi.

Ṭabarī, M. ibn J. (1991). Jāmi 'al-Bayān 'an Ta wà̄ Āy al-Qur'ān. Beirut: Dār al-Macrifah.

Ṭabāțabāīì, M. Ḥ. (2010). Al-Mīzān fì Tafsìr al-Qur ān. Tehran: Dār al-Kutub al-Islāmiyyah.

Ṭabrisī, F. ibn Ḥ. (1986). Majma 'al-Bayān li- Ulūm al-Qur ān. Beirut: Dār al-Márifah.

Ṭāliqānī, M. (1986). Partūȳ̄ az Qur ān. Tehran: Shirkat Sahāmī Intishār.

Țayyārah, 'A. 'A. al-F. (2003). Rūḥ al-Șalawāh fì al-Islām. Beirut: Dār al-'Ilm li-al-Malāyīn.

Tayyib, 'A. al-Ḥ. (1999). Atyab al-Bayān fì Tafsìr al-Qur'ān. Tehran: Intishārāt Islām.

Tha'ālabī, 'A. al-R. ibn M. (1997). Jawāhir al-Hisān fì Tafsīr al-Qur 'ān. Beirut: Dār Ihyā' al-Turāth al-'Arabī.

Tha'labī Nīshābūrī, A. ibn I. (2001). Al-Kashf wa al-Bayān 'an Tafsīr al-Qurāan. Beirut: Dār Ihyā’̀ al-Turāth al-'Arabī.

Thaqafì Tihrānī, M. (1978). Tafsīr Ravān Jāvīd. Tehran: Intishārāt Burhān.

The Holy Quran.

Ṭūsī, M. ibn Ḥ. (1982). Al-Tibyān fì Tafsīr al-Qur'ān. ed. Shaykh Āghābuzurg Tihrānī and Ahmad Qasīr 'Āmilī, Beirut: Dār Ihyā̄' al-Turāth al-'Arabī.

Zamashkharī, M. (2006). Al-Kashshāf 'an Haqāyiq Ghawāmiḍ al-Tanzīl wa Uyūn al-Aqāwāl fì Wujūh al-Ta wìl. Beirut: Dār al-Kitāb al-'Arabī.

Zuhaylī, W. ibn M. (1997). Al-Tafsīr al-Munīr fì al- Aqūdah wa al-Sharī'ch wa al-Manhaj. Beirut: Dār al-Fikr.

\section{Copyrights}

Copyright for this article is retained by the author(s), with first publication rights granted to the journal.

This is an open-access article distributed under the terms and conditions of the Creative Commons Attribution license (http://creativecommons.org/licenses/by/3.0/). 